Roger Williams University

DOCS@RWU

\title{
Eugenic Ideology and the Institutionalization of the 'Technofix' on the Underclass
}

Ann G. Winfield

Roger Williams University, awinfield@rwu.edu

Follow this and additional works at: https://docs.rwu.edu/sed_fp

Part of the Education Commons

\section{Recommended Citation}

Winfield, A. G. (2018). "Eugenic Ideology and the Institutionalization of the 'Technofix' on the Underclass." In Canestrari, Alan S. and Marlowe, Bruce A. The Wiley International Handbook of Educational Foundations. Boston: Wiley-Blackwell Publishers.

This Book Chapter is brought to you for free and open access by the Education at DOCS@RWU. It has been accepted for inclusion in Education Faculty Publications by an authorized administrator of DOCS@RWU. For more information, please contact mwu@rwu.edu. 


\section{Eugenic Ideology and the Institutionalization of the 'Technofix' on the Underclass}

This scenario for the twenty-first century, in which China assumes world domination and establishes a world eugenic state, may well be considered an unattractive future. But this is not really the point. Rather, it should be regarded as the inevitable result of Francis Galton's (1909) prediction made in the first decade of the twentieth century, that "the nation which first subjects itself to rational eugenical discipline is bound to inherit the earth" (p. 34)” (Lynn, 2001 p. 320).

Constructed notions of identity, political divisiveness, discrimination, and superiority along racial, ethnic, and class lines have historically been, and are currently, rife within cultural systems around the globe. Richard Lynn (2001), infamous for his decades of work on the relationship between race and intelligence, represents an increasingly emboldened group of historians, scientists, and educators in the present whose arguments are not only redolent of early twentieth century eugenic rhetoric, they are virtually indistinguishable. Eugenicists have argued for over a century that intelligence and moral character, heritable and hierarchical by race, are being threatened by prolific breeding by the 'unfit,' wanton miscegenation, and an increasing barrenness (by choice) among women of 'superior' genetic stock. Thus far, eugenic discourse has focused primarily on the superiority of the white, Nordic race, but for present-day eugenicists China and other East Asian countries, having controlled what Lynn calls 'dysgenic fertility,' are in a position to colonize and impose eugenic programs around the globe.

The twentieth century witnessed a global enactment of deeply embedded tenets of scientific racism: empires have been created and destroyed, East/West tensions have waxed and waned, armed conflicts, characterized by various forms of 'cleansing' or the production of the 'Final Solution,' have erupted on every continent; we have seen the emergence of the 'Third World,' along with decolonization and liberation movements; enormous, continuing shifts in global power structures, and wealth distribution infrastructures that mirror an underlying analysis of relative human worth.

Citing the ancient Egyptians, the Hindu caste system, and many cultures in preColumbian Asia, Africa, and the Americas, Lauren (1988/1996) refers to the "nearly universal nature of what we now call 'racial' consciousness, which has been independently discovered and rediscovered by various white and non-white peoples alike” (p. 5). Despite this, however, the white, Western world eclipses by far all preceding examples in its proclivity to use outward genetic expression as a basis for widespread discrimination. Lauren traces the tradition of race prejudice from Greek antiquity, quoting Aristotle's depiction of peoples hailing from the colder regions of Europe as "deficient in skill and intelligence" and those of Asia as "lacking in spirit [which is] why they continue to be peoples of subjects and slaves” (quoted in Lauren 1988/1996 p. 6). Surely, the collective memory produced by the Western canon was in operation for the likes of Lothrop Stoddard (1920) (who wrote The Rising Tide of Color: against White World Supremacy) and Madison Grant (1916) (who wrote The Passing of the Great Race). Upon what else could J. H. Curle (1926) have relied, writing in his book Our Testing Time: Will the White Race 
Win Through? that "as Man stands out at the head of Nature, so I believe that the white race stands out at the head of humanity. This may seem self-evident to us whites; but to a cultured Chinaman, say, or a haughty Arab, who thinks of us as upstarts, it may not be evident at all” (p. 77).

Global eugenics, or what Black (2003) refers to as 'eugenic imperialism' may be traced to the year 1912, when the First International Congress of Eugenics was held in London with the intention of contending with what American eugenicists saw as the "biological cesspool" that was mankind (p. 235). The central clearinghouse for the international movement was the Carnegie funded Eugenics Record Office (ERO) at Cold Spring Harbor, New York. There were, however, various agendas at work, or what some scholars (Stepan 1991; Briggs 2002) have referred to as hard and soft eugenics, referring to Mendelian genetics and neo-Lamarckian concept of the inheritance of acquired characteristics respectively. Each national movement shared a concern for inherited mental degeneracy and for the supposed negative effects of race mixing, but the scientific explanation and justification varied. While eugenic research in the United States and Britain centered around Mendelism, Scandinavia and Germany adopted it to a somewhat lesser degree. Eugenicists in Russia, France, and Latin America rejected the notion of Mendelian inheritance altogether and instead favored the neo-Lamarckian concept of inheritance of acquired characters. The end result was manifest in differing emphases regarding selective breeding, sterilization, immigration restriction, and anti-miscegenation laws for the Mendelians, and a focus on social policy in the area of environmental and public health for the neo-Lamarkians.

In either case, it is instructive to consider the workings of eugenic ideology in the present, and especially the progressive language through which this ideology has been perpetuated for over a century, for it is just here danger resides for countries around the globe. Consider, for example, the words of Margaret Sanger (1992) so revered, and rightly so, for providing women with the ability to control their own reproduction.

Every single case of inherited defect, every malformed child, every congenitally tainted human being brought into this world is of infinite importance to that poor individual; but it is of scarcely less importance to the rest of us and to all of our children who must pay in one way or another for these biological and racial mistakes (Sanger, 1922).

We must be willing to incorporate into our understanding that embedded ideology may exist in places about which we feel righteous, places that look like social justice, in our very conception of what it means to be "at risk." Such blindness, or ideological regression, exists in our national love affair with Ruby Payne, and her blatantly racist, deficit-theorypromoting montage that was heavily promoted in twenty-first century professional development workshops and handed out to teachers en masse around the country. We must of course value the desire to work towards equity and embrace social justice, but our vigilance can never rest. Gorski (2005) had it right when he said that what is most dangerous is the "way some of us - people ostensibly committed to equity education contribute to this regression by latching on to trendy "experts" without sufficient critical analysis of their ideas” (p. 2).

Public memory in the twenty-first century continues to be a product of three essential spheres: elite manipulation, symbolic interaction, and contested discourse (Bodnar 1994). Each of these spheres is enacted within school curriculum, the political 
discourse of nationalism, and within the vernacular discourse of public opinion. A 1994 Newsday article in which Richard Lynn explains his position

What is called for here is not genocide, the killing off of the population of incompetent cultures. But we do need to think realistically in terms of the 'phasing out' of such peoples.... Evolutionary progress means the extinction of the less competent. To think otherwise is mere sentimentality (Lynn, cited in Newsday, 11/9/94).

Clearly then, effective rebuttal to the current climate will require an integrated effort. Absent concerted resistance, twenty-first century school reform in the United States and elsewhere promises to solidify, rather than release children from historically rooted mechanisms for sorting, testing, and tracking, or the identification of those supposedly suited for 'gifted,' or vocational education, not to mention the international test score comparisons, financial inequities, non-English (or other dominant language) speaking students, vouchers, privatization, 'at risk' students, and new forms of 'apartheid schooling,' which all characterize the dialogue about schooling today both in the U.S. and elsewhere. If, as Grumet (1988) observed, school curriculum is best defined as what the older generation chooses to tell the younger, then schools potentially control not only what we remember of the past, but what we believe about the present and hope for the future. Internationalized, the implications are stunning.

An internationalized perspective of the field of education provides a unique opportunity to dissect the intertwined nature of education policy, economy, race, and the global influence of ideology and empire leading to potentially devastating possibilities. An examination of the combined influence of official and vernacular cultural expressions (Bodnar 1992) may explicate the ways in which ideological residue exacts standards, often invisible, on both cultural leaders and public sentiment alike. Within public memory, fundamental issues about how societies are organized, the negotiation of internal power structures, and constructed meanings of past and present often subsume specific economic and moral problems and it is here that we see the politics of culture writ large. Class, race, gender and identity politics are part of the discourse, but the argument is really about the interpretation of reality, rooted not only in past/present time dimensions, but also in inherent contradictions within social systems. We know that schooling everywhere has long been a site of enactment for these interpretations, dictated by whomever holds power. In this chapter I hope to shed light on this process by showing the ways in which ideological texts operate within the social context, impacting civic life on all fronts. Pinar (2004) has articulated the degree to which official national stories, ubiquitous in school curricula, often hide other truths such that they create an "illusion of truth being on the social surface, when it is nearly axiomatic that the stories we tell ourselves mask other, unacceptable truths" (p. 38). On every continent, one unacceptable, hidden truth exists in the form of eugenic ideology. All over the globe people who are poor, dominated, or seen as socially deviant are routinely disregarded, dismissed, or brutalized by governments and institutions who model the imperialist intentions of the west.

\section{Theory into practice}

"We thought for a long time that we belonged there, that we were not part of the species. We thought we were some kind of, you know, people that wasn’t 
supposed to be born” (Fred Boyce, 11 year inmate of the Fernald School in

Waltham, MA). http://www.cbsnews.com/news/americas-deep-dark-secret/

Just to the west of Boston, Massachusetts, a sprawling 186-acre site is home to what is now known as the Walter E. Fernald Developmental Center, the Western hemisphere's oldest publically funded institution for the developmentally disabled. When he was eight years old, Fred Boyce's foster mother died and the State of Massachusetts committed him to Fernald State School (as it was known at the time), diagnosed as a "moron" and set to work in the fields raising the vegetables that fed the school inmates. Tests showed that Boyce's intelligence was within the normal range, and as D'Antonio has shown, "the school made sure" that at least 30 percent of the children at Fernald were of normal intelligence, an intention not lost on Boyce who noted "you had to have somebody with a certain level of intelligence in order to run the place": the children at Fernald grew the food, cared for the livestock, cobbled the shoes and sewed the clothes. The proliferation of testing and tracking policies taking place in American public schools provided a steady stream of children deemed 'feebleminded' and subsequently sent to schools like Fernald and 100 other institutions like it.

Recent scholarship has uncovered what amounts to state-sponsored abuse in institutions across the country: at Fernald, overflowing dormitories, physical and sexual abuse, and experimentation on children by researchers from Harvard University and MIT funded by the Quaker Oats Company (D’Antonio 2005)

In 1912, during the discussion portion of a presentation to the Massachusetts Medical Society by W. E. Fernald, an audience member, Grace Boehne, brought up the case of a young boy,

We have had one other child in special classes that has been an entire failure during his entire school experience. This boy, Frank, was continually in trouble, but he was sent from the institution as a normal child and put to work. He made a failure on the farm to where he was sent and belongs to a special class at the present time, though he has had to leave school because of his bad physical condition.

The untold miseries of this child's experience belie the invective embedded in the ideological rationale driving the state's treatment of the boy: it is difficult to deny the extent to which this amalgam represented a blueprint which was to be infused into the infrastructure of virtually every major social institution in the $20^{\text {th }}$ century especially, for the purpose of this chapter, our modern system of education. In order to fully appreciate and understand the extent to which we, in the present, are living within an ideological framework which, in the context of our humanistic self-talk, seems draconian in the extreme, we must delve in to the minds and rationalizations, actions and legacy of the purveyors of eugenic ideology. Why was Frank an "entire failure" and what caused his "bad physical condition"? More to the point, what was the mindset of the adults around him that lead them to classify, diagnose, and place him as they did. Namesake of the abovementioned school Walter E. Fernald's 1912 presentation is a good place to start as he carefully outlines an analysis that was to drive public policy for decades, and I will argue, still does. First, though, what is eugenics?

\section{Making the world a better place through eugenics}


The term "eugenics," introduced by Francis Galton in 1883, captured the spirit of the survival of the fittest mandate used by Social Darwinists during the latter half of the nineteenth century, but couched it within a growing turn-of-the-century progressive sentiment. From the Greek eugènes, meaning wellborn, eugenics sought to put hereditary knowledge to social use by controlling genetic 'stock' of nations through policies controlling breeding, marriage, and immigration. Although best known for its use by the Nazis, eugenics was most enthusiastically embraced by the United States and Britain first, with subsequent movements being established in Germany, France, Italy, Norway, Sweden, Denmark, Russia, Cuba, Brazil, Peru, Mexico, Canada, and Japan (Stepan 1991; Kuhl 1994; Fredrickson 2002).

In the United States of America between the late $19^{\text {th }}$ and mid-20 th centuries, hundreds of thousands of children and adults were victims of the eugenics movement. Groups and individuals were affected not only as a result of the movement's three-pronged policy approaches governing forced sterilization, anti-miscegenation laws, and immigration restriction: but also through increasingly common testing practices in schools, socially mediated mandates regarding dating and love, and through the daily lives of social practitioners, legal scholars, teachers, social workers, and the clergy. Indeed, the infusion in to virtually every capillary of the social and institutional life of Americans saw, for example, the wide-spread institutionalization of those spuriously diagnosed as 'feebleminded,' the enactment of compulsory schooling laws across the country driven in part by their capacity to test, sort and track children from the earliest possible age into predetermined categories, as well as a complex code of 'moral' imperatives dictating marriage and family planning and definitions of wholesome American identity. These dictums originated from the most esteemed halls of academia and promoted an insistent and pervasive message was of warning: the devolution of society was at hand, a great 'mongrelization' threatened the nation and it was incumbent upon every citizen to heed the alarm and participate in restoration of American 'greatness.' The 'internal threat' identified by the chorus of proselytizers fell into roughly three areas: urban and rural poor whites, all races and ethnicities other than white, and anyone deemed socially deviant, sexually deviant or 'feebleminded' which included the mentally 'unfit,' unwed mothers, young boys who masturbated, basically anyone whose poverty, isolation, language, or habits rendered them unacceptable by 'polite' society.

It was within this context that our modern system of education was developed. Our so-called 'Fathers of Curriculum' ${ }^{\text {i }}$ were active believers in the eugenic assumption of relative human ability as defined by heredity. The underlying desire to purify the White race - a desire that continues to be pursued both overtly and covertly in policy briefs all over the country and all over the world, was superceded in American education by a perceived necessity to sort and classify students according to their inherited lot. This ideological legacy has morphed and dodged its way into the present on a number of fronts and is embedded in everything from foreign policy, housing policy, and healthcare, to juvenile justice, and standards and accountability in education.

Governmental uses of eugenically rooted ideology to impose what Nancy Ordover (2003) has called the 'technofix' on the underclass. From phrenology to social Darwinism, it is important to note that in the US, eugenics was but one of many iterations of racialized scientism in the $19^{\text {th }}$ and $20^{\text {th }}$ centuries. The capacity of this consistent thread throughout 
intellectual history to respond to and incorporate changing historical contexts is captured well by Ordover (2003) when she notes that even in the early $21^{\text {st }}$ century,

eugenics has always been an extremely nimble ideology. It cannot be isolated from the movements it bolstered and was conscripted by: nationalism, "reform-oriented" liberalism, out-and-out homophobia, white supremacy, misogyny, and racism. Its longevity relies on these confederacies for the simple reason that even as one falls into relative disrepute, others remain intact (p. xxvii).

As an analysis of the current state of affairs for the same populations targeted by eugenicists a century ago seems to indicate, there may a direct correlation between the extent to which the eugenics movement was dismissed and eradicated from our national historical narrative (prompted by the rise of the third Reich) and the degree to which its full operational intent and potential continues to be realized. In order to really get at the implication here requires that we as a society and as individuals fully contend with both the historical rootedness in eugenics of our most trusted and beloved institutions, and also of the extent of our own culpability. After all, this concerted governmental and societal effort to wipe out entire ethnic groups was pursued not by societally marginal hate groups but by progressives: the nations most respected universities, esteemed scientists and professors, government agencies and officials and wealthy philanthropists and industrialists were acting on an idea which was fully aligned with the nation's sense of self, prosperity and good works versus devilish idle, the coming together to make the world a better place: from native genocide to chattel slavery, we have been driven by the myth of progress and betterment.

Let us now revisit W.E. Fernald and his description of the problems and solutions as he saw them. In a 1912 address to the Massachusetts Medical Society Fernald told his audience that

The past few years have witnessed a striking awakening of professional and popular consciousness of the widespread prevalence of feeblemindedness and its influence as a source of wretchedness to the patient himself and to his family, and as a causative factor in the production of crime, prostitution, pauperism, illegitimacy, intemperance and other complex social diseases.

The term 'feebleminded' was considered at the time to be a precise psychiatric category, along with 'moron,' idiot' and 'imbecile' and was largely utilized to refer to those children and adults who could work and function in society but who were thought to be unable to compete with their 'normal' peers. Psychologist Henry Herbert Goddard popularized a fear-based national sentiment with the 1912 publication of his book The Kallikak Family: A Study in the Heredity of Feeblemindedness in which he traced the genealogy of a revolutionary war soldier named Martin Kallikak who purportedly dabbled with a 'feebleminded barmaid' before ultimately marrying a 'good Quaker woman.' The book traced the progeny of both lines, advancing the biological deterministic argument that heredity is the single most important factor in determining the health and well-being of societies. Through its multiple printings and the rising prestige of its author, the book was a pillar of the eugenic narrative, though ultimately shown to have utilized doctored photographs to create dark menacing caricatures of supposedly feeble-minded adults and children (Gould).

In his address, using the framework of the recently rediscovered theory of Mendelian genetics, Fernald went on to explain the myriad ways in which "hereditary defect is the result of protoplasmic defect in the germ plasm of the family stock." Further, 
he claimed, "there is some reason for the belief that the remarkable shift of population from rural to urban conditions in the last half-century with the resulting industrial social stress, and a greater liability to syphilis, tuberculosis and alcoholism, has increased the ratio of defectives in families with hereditary predisposition.” Interestingly, Fernald incorporates what we would today call environmental and social factors into his analysis, but only for the purpose of pointing to underlying hereditary factors. "Recent study of certain isolated rural communities in Massachusetts" Fernald tells his audience of doctors, "where the more vigorous families have migrated for several generations, shows a marked deterioration in the quality of the population, with a large number of the feeble-minded and a notable amount of immorality, intemperance and shiftlessness." Rural or urban, man, woman or child, "the feebleminded are a parasitic, predatory class, never capable of self-support or of managing their own affairs." Then, as now, a great deal of emphasis was placed on economic concerns with repeated reference to the financial hardship on the state for the required care of adults and children deemed 'unfit.' Nevertheless, 'there is an urgent demand for greatly increased institutional provision" the cost of which "will be great, but not as great as the present cost of caring for these same persons, to say nothing of their progeny, in future generations." Increased institutionalization, he argued, "would cost less money [and] be more economical in social life and of immense value morally."

Institutionalization of hereditary defectives was essential in the minds of eugenicists, in part, because it allowed for control of what was seen as the primary driver of unchecked breeding: women. "Feeble-minded women are almost invariable immoral" Fernald told the doctors, and, if married, are "twice as prolific as the normal woman ... the only way to reduce to number of feeble-minded is to prevent their birth." Of particular concern was the "high-grade female ... the most dangerous class" because in addition to the high birth-rate,

They are certain to become sexual offenders and to spread venereal disease or to give birth to degenerate children. Their numerous progeny usually become public charges as diseased or neglected children, imbeciles, epileptics, juvenile delinquents, or later on as paupers or criminals. The segregation of this class should be rapidly extended ... under strict sexual quarantine"

Fernald goes on to lament the fact that "we have no laws compelling this action."

The Anglo-Saxon respect for the liberty of the individual would make it difficult to enact laws compelling such custody. This difficulty could be approached by the suggested registration of the feeble-minded which would afford a basis for some sort of extra-institutional supervision and control.

Enter education. How convenient that an already established institutional mechanism existed that had already gained widespread societal acceptance and promotion. As Fernald and other eugenicists began to realize, education offered an alternative to their original plan to 'weed out' the 'unfit' within three generations through sterilization and control of marriages. After all, Fernald argued,

In a rational policy for controlling feeblemindedness it is essential that we recognize the condition in childhood. Our compulsory school laws bring every child to official notice. Every case of feeblemindedness should be recorded ... sooner or later the parents will probably be willing to allow their children to be cared for in the institution ... there are now special public-school classes for the feeble-minded in most of our cities and large towns. These classes insure diagnosis 
and treatment at an early age, they help inform the parents as to the dangers of the condition, and they admirably serve as clearing houses for permanent segregation before adult life is reached. They should be extended and increased in number.

That education has long been regarded societally as both scapegoat and promise is well known. Eugenicists, having to acknowledge the constitutional right to 'life, liberty, and the pursuit of happiness' along with the realization that the 'unfit' were here to stay and would not be bred out within three generations, naturally turned to education (Winfield, 2007). The larger vision of racial purification and the maintenance of white, male hegemony required a complicit public. No matter that so many of those who needed convincing were marginalized and poor, as long as each group could be convinced that they were better than someone the equation would work.

One of the most visible popularizers of eugenic ideology was Dr. Alfred E. Wiggam, author of The Next Age of Man, The Fruit of the Family Tree, and the 1923 bestseller The New Decalogue of Science. Wiggam was a journalist and lecturer who "stood out for the way he melded eugenic science with statesmanship, morality and religion" (Kevles 1985 p. 59). Posters promoting his lectures picture Wiggam as an imposing bespectacled man, describe him as "The Apostle of Efficiency" and characterize his lectures as offering “A hopeful, helpful, inspiring, philosophy of life for these times." In addition to lectures entitled, for example, "Who Shall Inherit The World - The Strong or The Weak. The Intelligent or the Stupid?,” the posters boast of Wiggam's contributions to Reader's Digest (he was a staff writer), a regular newspaper column Let's Explore Your Mind, Good Housekeeping, Ladies Home Journal, American, Cosmopolitan "and many other magazines” (TCS-LOC) ${ }^{\mathrm{ii}}$. Regardless of the accuracy of the claims on many posters that Wiggam's column reached over five million readers a day, or that over a million people had paid to hear Wiggam lecture, it is clear that Wiggam was practically ubiquitous in American popular culture.

Reflecting the eugenicists' optimism for the role of education in furthering their cause, Wiggam (1927), joined the chorus of eugenicists who theorized about the potential role of education wrote that

Experimental education is going forward with such significant achievement, and is in the hands of so many brilliant and qualified men, that I am prone to believe that just here lie the chief hopes of our country's future. I am sure that here lie also our chief hopes of eugenics, for I believe that education, both in America and Europe, is marching steadily forward towards four significant goals (Wiggam, 1927 p. 317).

The four goals outlined by Wiggam evidence the degree to which ideological constructs provide an infrastructure which is unfazed by the changing context of time and circumstance. They are, of course, startling for their familiar ring, but might better be regarded as emblematic of the ubiquity of the past in the present.

\section{Education in service of eugenics}

The first of Wiggam's goals for the utilization of education in the furthering of eugenic intent was the measurement of the mind or, as Wiggam put it, the provision "for the first time in the world's history, [of] a true knowledge of what it (sic) is they are trying to educate" (1927 p. 318). The "it" in this case being children, testing offered the provision of a method of classification and an apparent way to measure for the presence of ability. 
Testing provided eugenic ideologues with a scientific legitimacy they craved, especially after the stinging rejection of their claims of heritability by geneticists (Paul 1998). Regarding the role of testing and the measurement of progress eighty years later, then Secretary of Education Margaret Spellings remarked in a speech marking the fifth anniversary of the No Child Left Behind Act in January 2007,

as for testing, I believe President Bush is absolutely right when he says you can't solve a problem unless you diagnose it. If you don't know a child is having a problem, how can you fix it? If you don't measure, how do you know that students are making progress? (Spellings 2007b).

Given that scientific inquiry requires a standard by which to measure data, mental testing was developed wholly around the standard of the white, young male population. Thus, the systematic devaluing of all that could not be tested was realized as considerations of culture, learning style, power differentials, access, etc. were not taken into account in the new zeal to measure and sort students.

The second of Wiggam's (1927) goals was the measurement of educational progress in order to tell "just how much or how little educated a man really is" (p.319). Here we find the advent of the notion of accountability closely intertwined with the everappealing idea of progress where education is concerned. Notions of progress, educational aims, and targeted populations have been the subject of school reform efforts for over a century, with opposing sides often overlapping, obscuring and co-opting each other's claims, goals, and tactics. Consider that former Secretary of Education Paige, in a speech to the Brookings Institution, implores his audience to

remember that accountability is a movement that started at the grassroots level many years ago. It is an essential part of educational reform. No Child Left Behind is just the latest form of it ... now every child must have the same chance to learn in our educational system: rich or poor, rural or urban, English speaker or not, African American or Asian American, Latino or White, easy learner or learning challenged (Paige 2003).

Lest you feel warm and fuzzy about this, however, or pleased that emancipation efforts in the 60s and 70s had reached the highest levels of government, keep in mind that, in Paige's words

we will generally hold the line against soft accountability. We are determined to make the law work well and to fully implement the law, as intended. I realize that some states may soften their standards, but my department will urge that standards not be weakened over time. In addition, those states who attempt to soften accountability will have to answer to parents, taxpayers, the business community, voters-everyone. They will fool no one by lowering standards. Citizens themselves will provide a powerful check against retrenchment (Paige 2003).

Lipman (2004) characterizes the standards and accountability movement as one in which the state has abrogated its responsibility. The education of children becomes an enforced effort, an enterprise characterized by punishable offences, meted out by state and federal agencies who are now in sanctioned positions of "overseer, judge, and dispenser of rewards and punishments - as well as subcontractor to corporations and supplier to the armed services” (p. 188). At the same time, no provision is made societally for the systemic inequities. From the “Old Deluder Satan Act” of 1647, to (phrenology enthusiast) ${ }^{\text {iii }}$ Horace Mann's common school movement, we still rely, for example, on property taxes to fund 
school. Educators and communities are defined by an outer-imposed system whose consequences further entrench poverty and inequity. Wiggam would be pleased, I think, with the extent to which his first two goals have been realized. Furthermore, he would, in fact, have been quite understanding about the inclusion of a social justice perspective in the language for Wiggam understood the public's need to feel good about itself, and its own motives. Operating within an era of decidedly progressive pubic sentiment he had previously cautioned his readers that heredity was not the definitive cause of human difference "since the factors of heredity and environment are not separated" (Wiggam 1924 p. 10). While Wiggam allowed for the possibility that environmental factors played a role in success and social standing, he nevertheless felt sure that "heredity and not environment was the chief cause” (p. 10). Eugenicists, having reconceptualized Social Darwinism to appeal to an increasingly Progressive public sentiment characterized by the suffrage movement, the push to ban child labor, temperance and a building move to uplift the poor famously represented by Jane Addams and Chicago's Hull House, understood that an overly deterministic stance would be deleterious to the acceptance of their message by the general public.

The same might be said of the advocates of the twenty-first century No Child Left Behind Act who claim that "under No Child Left Behind, parents have a powerful and profound guarantee that each and every student will receive a quality education ... accountability is about creating a culture of responsibility, performance, and quality" (Paige 2003). Only a culture that is clear on the importance of language, and on its own role in creating itself, could result in Tom Corwin, Associate Undersecretary for Innovation and Improvement of the U.S. Department of Education's Office of Innovation and Improvement who noted that

the catch-phrase "No Child Left Behind" itself embodies [the theme of high standards], for the law really does require educators at all levels to set achievement standards applicable to all children, of all racial and ethnic groups and including those who are economically disadvantaged, limited English proficient, or disabled (Corwin 2003).

As in the past, policymakers remained cognizant of the public's need for evidence that civic effort to improve society and, indeed, themselves was not wasted. The public, having witnessed the reform efforts of the 1970s fail to a large extent, embraced the language of that era but failed to interrogate the systemic reasons, and its own complicity, for its failure.

Education's third significant goal, according to Wiggam (1927) was the adjustment of men and women in industry, and in economic and political life such that individuals can avoid being "subjected for life to the wrong occupation, the wrong kind of work" (p. 319). The feebleminded, Wiggam had written previously, "are merely mental children” (1924 p. 355) and must be directed into a station in life most befitting their capacity. Wiggam continued:

This especially applies to the higher grades of feeble-mindedness, the morons.

Many morons are most effective factory workers and enjoy the monotony of tending simple machines or carrying out simple industrial processes (Wiggam 1924 p. 355).

The public was primed to feel good about the development of technical and agricultural tracks in schools since, after all, factory workers "enjoy the monotony," just as they were able to feel good about the provision of 'gifted and talented' education programs so their 
own children might not be mixed with feebleminded classmates. By phrasing this educational goal in terms that connote happiness and prosperity for all, Wiggam was able to achieve the ultimate interconnection between the purpose of school and the purpose of life. The idea that individual citizens might hold the right to decide for themselves what constitutes happiness, or success, was not part of Wiggam's equation. Appeals to America's opportunity and manifest destiny satisfy the public desire to feel good about education and all those offspring.

Corporate and bureaucratic influence in education, in particular in the setting of aims and goals for the educational endeavor, has a long history. Philosophical pragmatism, long the philosophical lynch pin of school policy and practice, has its roots in business values (Pinar, 2004). These roots begin with Horace Mann's assumption that education is limited to schoolhouse walls (thus paving the way for bureaucratization of the institution), to the continuing assumption in the present that the primary goal of schools is to prepare students for the world of work. While teaching students to think might accomplish this goal, a workforce that questions the status quo is undesirable. Secretary of Education Margaret Spellings (2007) was clear about the role of business in the perpetuation of the myth of NCLB. Noting that the business community was key to the passing of the law in 2000, she implored the business community to "play an even greater role this year." Spellings continued

I've also been impressed with the personal commitment of several CEOs who I want to mention even though they're not able to be here today, including Craig Barrett (Intel), Art Ryan (Prudential), [and] Ed Rust (State Farm). From my point of view, regardless of where you're starting from, active, engaged business communities are key to improving our schools ... [they] know better than anybody that our education system has not kept pace with the rising demands of the workplace ... half of African-American and Hispanic students fail to graduate from high school on time. Two-thirds of high-growth, high-wage jobs require a college degree, but only a third of Americans have one (Spellings 2007b).

School accountability, standards in education, and the economic "bottom line" are all defined through the pragmatic value that education provides business, today as much as during Wiggam's time. Although Spellings implies a desire to increase African-American and Hispanic graduation rates, there are plenty of researchers who have an explanation for their supposed lack of achievement. Following Richard Lynn, Linda Gottfredson ${ }^{\text {iv }}$, of the School of Education at the University of Delaware writes in her (2005) article What if the Hereditarian Hypothesis is True? about the promise of what she terms ' $g$ theory.' Gottfredson is quick to note that her views are often 'spurned'

Is the average Black-White difference in phenotypic intelligence partly genetic in origin? Much relevant scientific evidence has accumulated since Jensen first asked the question in 1969, but openly addressing it still seems as politically unacceptable today as it was then. Taking the question seriously raises the possibility that the answer might be yes, which for some people is unthinkable. It is therefore no surprise that such research and researchers are often evaluated first against moral criteria and only secondarily, if at all, against scientific ones (p. 311).

$G$ theory, distinct from 'culture-only theory,' regards both individual and group differences in intelligence as substantially embedded in biology rather than culture. Intelligence theory, 
according to Gottfredson, suggests that those with lower intelligence' relative risk for "multiple health and social problems" might be lowered if

a) education and training were better targeted to their learning needs (instruction is more narrowly focused, non-theoretical, concrete, hands-on, repetitive, personalized, and requiring no inferences); (b) they were provided more assistance, and direct instruction in matters of daily well-being that we expect most people acquire on their own (e.g., learning how best to avoid various kinds of illness and injury); and (c) health care providers, social service agencies, and other institutions removed some of the unnecessary complexity (e.g., inadequate or overly complex labeling, instructions, and forms) that often impedes full and effective use of services, medical regimens, and preventive care by the less able. Less favorable genes for $g$ impose constraints on individuals and their helpers, but they certainly do not prevent us from improving lives in crucial ways (2005 p. 318).

How redolent this is of the sentiments of Henry Herbert Goddard (of Kallikack fame), a student of G. Stanley Hall and the first American psychologist to recognize the potential of intelligence testing for furthering eugenic ideals. Differences in children required different educational responses, Goddard (1912) wrote, and furthermore, the greatest threat to society, was the 'high grade', or 'moron' type of feeble mind because although they were unfit (but not unable) to reproduce, they nevertheless were able to function in society and thus were a threat to the gene pool.

Here we have a group who, when children in school, cannot learn the things that are given them to learn, because through their mental defect, they are incapable of mastering abstractions. They never learn to read sufficiently well to make reading pleasurable or of practical use to them. Under our present compulsory school system and our present course of study, we compel these children ... and thus they worry along through a few grades until they are fourteen and then leave school, not having learned anything of value or that can help them to make even a meager living in the world (Goddard, 1912 p. 16).

Thus was the central dogma of eugenics, that "poverty and its pathologies, like affluence and its comforts, were in the blood - and not in the environment in which human beings were conceived, born, and developed" (Chase 1975 p. 149). Past and present, we are compelled by our own ideological roots to seek out a scientific way to establish difference, and to establish divergent paths for students that have different abilities, both of which require, and enjoy, public support.

Finally, Wiggam's fourth goal is perhaps the most alarming for its insidiousness and invisibility. Wiggam called for the "measurement and education of moral character and a subsequent move away from focus on the intellect” (1927 p. 320). This is clearly evident in Gottfredson's call for instruction that is "narrowly focused, non-theoretical, concrete, hands-on, repetitive, personalized, and requiring no inferences” above. Antiintellectualism pervades education today, just as it has for the past century. Despite the fact that one might object that the first three of Wiggam's goals, measurement of the mind, measurement of the progress of education, and the alignment of education with the economic needs of society, by observing that they carry out the fourth goal by default, antiintellectualism is a serious educational trend in its own right. An analysis of the themes in educational policy over the ensuing seven decades show little deviation from the goals outlined by Wiggam in 1927. 
The educational goals outlined by Wiggam were widely implemented in school policy and practice and are reflected in the theories of leading American early twentiethcentury educators such as Bobbitt, Thorndike, and Hall (Winfield 2007), the "Fathers" of our modern system of education. As we have seen, the goals have changed little since the early twentieth century when promotion to the literate public and audiences of educators took place via an active lecture circuit, newspapers, magazines, and popular and educational writings, college textbooks ${ }^{\mathrm{v}}$, and teacher training manuals. Educators have long been instrumental in translating eugenic goals to the public as evidenced by an analysis of the occupational background of the 144 leading eugenicists who contributed to the popular 1932 pamphlet What I Think About Eugenics the majority of whom (47) were educators $^{\mathrm{vi}}$ (Ludmerer 1972). The realization of the desired goal of achieving a racially pure, eugenically sound society required that the nations youth be ideologically convinced.

The ubiquity of issues of racism, sexism, and homophobia in the media demonstrate that the wounds of the past are raw, unable to heal, exacerbated daily, while for much of the latter half of the twentieth century many of the nation's youth regarded racism and discrimination as issues from a bygone era. Consider that incidents of college students attending racist parties have received national attention of late. Indeed, the NAACP is investigating three university parties during the first month of 2007 which featured fried chicken and fake gang apparel, and a "Bullets and Bubbly" party where students held fake machine guns and 40-ounce malt liquor bottles (Schafer 2007). Another student, documented in an article by Wise (2005) exemplifies an almost blasé approach to human difference:

Chira, for his part, seems more confused than dangerous. All in the same breath he insists he is not a Nazi or neo-Nazi, but that he is a National Socialist (the term for which Nazi is shorthand). He insists he is not a white supremacist, a racist, or antiJewish, yet claims to be a supporter of the American National Socialist Movement (NSM), which calls for citizenship to be limited to those who are non-Jewish, heterosexual whites, and which group praises Hitler on its website (Wise 2005).

Yet another example comes from the fraternity Sigma Alpha Epsilon at Oklahoma University where in 2015, students were caught on film reciting a fraternity chant which included references to lynching and boasting that there would never be an African American member (https://www.nytimes.com/2015/03/11/us/university-of-oklahomasigma-alpha-epsilon-racist-fraternity-video.html?_r=0).

In considering the constraints on our own future imaginings, it is instructive to reflect on the transmogrification of eugenic ideology which took place as Americans realized that in light of the holocaust, eugenics could no longer be couched in a rhetoric of morality, civic duty, or familial purity. Just as eugenics had replaced Social Darwinism decades earlier, racialized scientism morphed again after WWII into a clean-cut antiintellectualism. We are responsible for much. Generations of Americans have not learned the truth about the historical legacy that creates the way they see the world in the present. Furthermore, as Pauline Lipman points out, "accountability language, practices, social relations, and ways of valuing and thinking constitute a discourse of social discipline and subjugation that is highly racialized [these policies] legitimate and produce the regulation and control of youth of color" (p. 171) the implications of which are pertinent not just to young people but to the elders who conscript the routine. 
Pondering the implications of ex-Seinfeld star Michael Richards' bigoted tirade at a comedy club that sparked a furry of national attention about the existence of racism in America, CNN talk-show host Paula Zahn wondered "is there an inner racist in many of us, just waiting to explode? ... is racism thriving today, just underneath a well-masked surface of political correctness and civility?” (Zahn 2006). Pinar says that "we cannot begin to respond to the displaced and deferred racism and misogyny we suffer today until we face the internalized consequences of our decades long subjugation, namely a pervasive and crippling anti-intellectualism” (p. 9). How, though, do we define anti-intellectualism? We would be remiss if we limit our definition to, say, finding pleasure in mind-dulling media spew, or comfort in having a reassuring image reflected back in spoon fed curriculum. The notion of internalized ideology carries with it implications far more unbecoming than a base definition of anti-intellectualism alone would account for. Our own complicity in internalizing hierarchical notions of culture, along with the provision of an exalted status for intellectualism may, in part, mask our own culpability in the perpetuation of inequality. White Americans have internalized much: racism, misogyny, homophobia, and white supremacy are a part of the pabulum of our youth, absorbed, masticated, personalized. We are most dangerous when we proclaim our innocence, our immunity, to the racialized scientism that is the past we all share.

With few notable exceptions ${ }^{\text {vii }}$, there has been a veritable dearth in the public discourse regarding the role of the United States in pioneering racial purification thought and policy both before, and since, WWII. Through the middle 1970s, thousands of people were sterilized in American institutions. In the mid-1990s, a white judge in California sentenced an African American woman to the surgically implanted birth control Norplant while the Pioneer Fund, founded in the 1930s, continues to fund explicitly racist academic research like that of Linda Gottfriedson. We are directed in the present by our inability (or reluctance) to see the ubiquity of the past in the perpetuation of racial divisiveness.

School curriculum (co-opted by a larger societal desire to manipulate the national narrative such that we are able to feel that we are in some way valuable, good, that intentions matter and supercede realities) becomes the site within which the older generations choose what is told to the younger generation. But do we know why, or even that, we choose as we do? We are complicit in the erasure, pawns of our own memory, even as we disregard the voices of 'others.' We talk about creating spaces for the voices of those who are silenced, yet because we are working within the very framework we are trying to dismantle, our efforts too often become recycled ones that end up perpetuating the status quo.

Public memory regarding post-WWII America describes a time of economic bounty and educational opportunity. The idyllic 1950s, deconstructed so well by Stephanie Coontz (1992), operated as a realignment of eugenic ideological constructs into governmental policies which acted as a cement for the white hegemonic status quo. As an example of this, of the millions of dollars in federal home loan underwriting that occurred after WWII, less than two percent went to non-whites resulting in a racialized wealth disparity denied by whites. Thomas Shapiro (2005) argues that wealth distribution is perpetuated by white inability to see the residual effect of institutionalized inequality and the extent to which they themselves benefit. Using schools as an example, Shapiro claims that since most parents are unable to judge schools for their children objectively, they instead rely on easy-to-observe markers like the race of students. These preferences raise 
the cost of home-buying in predominantly white neighborhoods (neighborhoods created by federal housing policies from the 1950s including redlining and blockbusting). Whites interviewed by Shapiro were insistent that regardless of any inheritance they received (from tens to hundreds of thousands) their current economic status was the result of wise stewardship and hard work on their part. Robert Asen (2002) understands the difficulty, arguing that "contestation accompanies processes of discursive construction” (p. 7). Even those who seek to resist inequity contend with incongruent interests both internally and externally. Indeed, "advocates have to sustain their visions against competing versions as they engage interlocutors. Through public debate and controversy, collective imagining itself is continually refashioned" (Asen 2002 p. 7).

Lipman argues the same thing from another angle, stating that school policy and curricula work together as a kind of shaping mechanism for the public imagining. When public education has as its core a system of centralized control and accountability designed to "regulate students and teachers and to redefine education around the skills, information, procedures, and results of standardized tests [it creates a] racialized discourse that disciplines African Americans students and their teachers and constructs African Americans in general as people in need of social control” (p. 71). Furthermore, Lipman argues, "these policies contribute to the formation of white supremacist culture and consciousness and the urban mythology of middle-class normalcy and whiteness" (p. 71). Lipman goes on to document the state imposed systematic degradation of living conditions in Chicago's public housing and the subsequent forced removal of a population of people (no longer needed for either their industrial labor or their votes) couched in the media, in light of the former, as a 'humanitarian' effort.

Efforts to regulate housing and family structure are rooted in eugenic logic and have lost little of their original intent in the translation. Wiggam (1924) reported that "from the Southwest comes another note of hope which I trust will be heard around the world - only by those, however, of the super-common stock." (p. 305). Quoting a "New York newspaper," Wiggam offers as a policy exemplar the following

Walter P. Fulkerson, a St. Joseph, Missouri banker, is building a row of houses for rent only to families which have children and to newly married couples...newlyweds, according to Mr. Fulkerson, will be allowed to occupy the houses with the provision that if there are no children within a year, the tenants will be asked to vacate. Whenever a child is born, Mr. Fulkerson announces, the rent for one month will be returned. And then follows perhaps the most important part of the statement, to a biologist: 'the houses are in one of the best residential districts.' This indicates a better average moral and physical stock than is found within the worst residential sections (p. 305).

The blurring of the lines between progressive reform efforts and conservative ones in public policy of all kinds has resulted in a stilted debate wherein neither side is clearly delineated (Winfield and Canestrari 2012). As an example, witness the attempt in Washington State to put an initiative on the November 2007 ballot that would require marriage license applicants to prove their ability to procreate and automatically nullify any marriage that had not resulted in procreation within three years. The Washington Defense of Marriage Alliance (WA-DOMA), formed after the Washington State Supreme Court upheld a ban on same-sex marriage, argues that "for many years, social conservatives have claimed that marriage exists solely for the purpose of procreation ... The time has come for 
these conservatives to be dosed with their own medicine" (Gadow 2007). At the same time as the national debate appears to have taken on bilious proportions, the actual margins of the debate have narrowed considerably over the past forty years. As Asen (2002) notes, for example, we have gone from an 'unconditional' war on poverty in the 1960s that recognized the multifarious nature of the population dynamic to a view in the 1980s and 1990s of poverty as a pathology, "a set of demeaning representations of poor people as delinquents, contract workers, and wards that drew on past characters and addressed economic conditions as moral drama” (p. 22).

How shall we debate, argue, and despair over twenty-first century education policy as over-reliant on standardized tests, and over the callous disregard for the social inequalities that are ignored? Perhaps, we should not debate at all. I suggest that to engage in the details of the manifestation of an ideological throughline to which we are utterly opposed is to have our strength sapped, our vision subsumed, our complicity masked. We already know that the present historical moment is engaged in a systematic devaluing of everything that is not tested, that the authority of official knowledge remains unchallenged in the curriculum, and that broad, liberatory aims for schooling have yet to be realized. What we are less clear about is why. The debate has not identified the core of itself, and as a result, liberals, progressives, conservatives, and traditionalists have too often blurred, blended, and overlapped. Stephen Steinberg (1995) understood this, writing that

the enemy depends on the so-called liberal to put a kinder and gentler face on racism; to subdue the rage of the oppressed; to raise false hopes that change is imminent; to moderate the demands for complete liberation; to divert protest; and to shift the onus of responsibility ... from powerful institutions that could make a difference onto individuals who have been rendered powerless by those very institutions (Steinberg 1995 p. 135 quoted in Ordover 2003 p. 131).

It is to history that we must turn in order to fully grasp our current state of affairs. It was the seventeenth century Puritans who not only established an enduring faith in the power of education to aid in the salvation of social ills and inadequacies, but also provided a form of social discourse that used competition to create a public sphere that was authoritarian, democratic, hegemonic and individualistic all at once (Roberts-Miller 1999). This model of public discourse is, as Roberts-Miller (1999) explains, "essentially static: one displays one's knowledge, presents one's evidence, possibly with the hope that others might be persuaded, but with no intention of changing one's own position ... to leave with a different relationship toward that initial argument - to reconsider it, for instance, - is to be defeated" (p. 172). The result of this provision was that one did not enter into the public discourse in order to discover what one believed; rather, one entered the discourse in order to convince and compel others to believe what was presented (Roberts-Miller 1999). The influence of this early parameter has ensured that, as we try, even internally, to re-evaluate what we know, meanings we have constructed from the very beginning, we are bound to resist. In addition, this model of public discourse has defined education as a conduit for training and advocacy rather than an environment of discovery and learning.

Much has been written about the foundation: the presumption of white supremacy in the decimation of native populations, the relentless acquisition of land, and the hierarchical and puritanical paradigm for the formation of a new nation. Built upon this substrate, we might begin the tracing with the contention of English physician and surgeon 
Charles White in 1799 who claimed that "on the basis of anatomical and physiological evidence ... blacks are a completely separate species, intermediate between Whites and apes" (quoted in Tucker 1994 p. 10) a notion which Thomas Jefferson, lauded for his attempts to pass the "Bill for the More General Diffusion of Knowledge," used to justify (externally, we should note) both slavery, and the exclusion of non-Whites from his educational aims. Fast forward though the next century where the disciplinary through line is refined and strengthened by the civil war, the publication of Charles Darwin's On the Origin of Species by Means of Natural Selection, or the Preservation of Favoured Races in the Struggle for Life, the subsequent application of 'survival of the fittest' mandate to social problems in the form of Social Darwinism, the coining of the term eugenics by Darwin's cousin Sir Francis Galton in 1883, and the development of the Progressive era at the turn of the century. Now we are ready to identify the through line as it has existed since the turn of the twentieth century, providing the primary lines of demarcation for the system of education within which we, our parents, grandparents, and children all have been educated. Portending twenty-first century 'standards and accountability' rhetoric, Charles Davenport declared in 1911 that "the relation of eugenics to the vast efforts put forth to ameliorate the condition of our people, especially in crowded cities, should not be forgotten" (p. 254). Davenport aptly reflects the deep-rooted ideological substrate that has defined the public debate over education ever since:

Education is a fine thing and the hundreds of millions annually spent upon it in our country are an excellent investment. But every teacher knows that the part he plays in education is after all a small one ... the expert teacher can do much with good material; but his work is closely limited by the protoplasmic makeup - the inherent traits of his pupils (Davenport $1911 \mathrm{p}$. 255).

Our legacy of Puritan inspired social discourse is reflected in the current era wherein “probation, retention, publication of schools' test scores, and constant media monitoring of test results have become public spectacle of failure ... promote a panoptic order of intense monitoring and surveillance” (Lipman 2004 p. 46). Education-as-failure is ubiquitous in the media, among the public, and in the rhetoric of the right and the left. There is nothing about the national debate about education that promotes engaged public attention to systemic inequity, or an acknowledgment of the residue of history which might lead to an emancipatory collective examination of the problems in schools. We who are engaged in the debate know that we are right, we have no intention of changing our position, we are not interested in defeat.

\footnotetext{
${ }^{\mathrm{i}}$ This is outlined in my book and especially true of John Franklin Bobbitt, Granville Stanley Hall, W.W. Charters, E.L. Thorndike, and generations of school administrators educated in the science of efficiency by Elwood P. Cubberley.

ii The Traveling Culture Series documents are available online through the Library of Congress. Source materials are housed at the University of Iowa libraries. According to the website, "The digital collection presents 7,949 publicity brochures, promotional advertisements and talent circulars for some 4,546 performers who were part of the Chautauqua circuit. These talent brochures are drawn from the Records of the Redpath Lyceum Bureau, held by the University of Iowa Libraries. One of the largest booking agencies for the Chautauqua performers, the Redpath bureau managed a vast talent pool. Performers and lecturers were familiar names as popular entertainers or well known in the political, religious and cultural
} 
worlds (http://memory.loc.gov/ammem/award98/iauhtml/tccchome.html). These documents will hereafter be referred to as TCS-LOC. I will further identify individual documents by their internet location tag line. iii See Tomlinson, S. (2005). Head Masters: Phrenology, Secular Education, and Nineteenth Century Social Thought. Tuscaloosa, The University of Alabama Press. for a full description.

${ }^{\text {iv }}$ Gottfredson has been the recipient of a number of Pioneer Fund grants over the past two decades. The Pioneer Fund was established in 1937 to fund research on intelligence and heredity. The Pioneer Fund website defines itself as "A nonprofit foundation who's purpose is to conduct or aid in conducting study and research into the problems of race, heredity and eugenics. Gottfredson's work has been used in the establishment of public and private policies regarding hiring quotas, "race-norming" on aptitude tests, and affirmative action.

${ }^{\mathrm{v}}$ For coverage of the extent to which eugenics appeared in both high school and college texts see Selden, S. (1999). Inheriting Shame: The Story of Eugenics and Racism in America. New York, Teachers College Press..

vi The full statistical breakdown of the backgrounds of contributors to the pamphlet What I Think About Eugenics is as follows:

\begin{tabular}{ll} 
Occupation & \\
\cline { 1 - 2 } Educator & 47 \\
Scientist & 22 \\
Clergy & 19 \\
Professor (lib. Art) & 16 \\
Physician & 10 \\
Author-Journalist & 8 \\
Politician & 5 \\
Lawyer & 4 \\
Philanthropist & 2 \\
Banker-Businessman & 2 \\
Other & 9
\end{tabular}

\section{References:}

Asen, R. (2002). Visions of Poverty: Welfare Policy and Political Imagination. East Lansing, Michigan State University Press.

Becker, C. L. (1935). Everyman His Own Historian: Essays on History and Politics. New York, Appleton-Century-Crofts.

Black, E. (2003). War against the weak : eugenics and America's campaign to create a master race. New York, Four Walls Eight Windows.

Bodnar, J. (1992). Remaking America: Public Memory, Commemoration, and Patriotism in the Twentieth Century. Princeton, NJ, Princeton University Press.

Briggs, L. (2002). Reproducing empire: race, sex, science, and U.S. imperialism in Puerto Rico. Berkeley, University of California Press.

Chase, A. (1975). The Legacy of Malthus: The Social Costs of the New Scientific Racism. New York, Alfred A. Knopf.

Coontz, S. (1992). The Way We Never Were: American Families and the Nostalgia Trap. New York, Basic Books.

Corwin, T. (2003). The No Child Left Behind Act: Where are We Now? Where Are We Going?

Curle, J. H. (1926). Our Testing Time: Will the White Race Win Through? Murray Hill, George H. Doran Company.

Davenport, C. B. (1911). Heredity in relation to eugenics. New York,, H. Holt and company. 
D’Antonio, M. (2005). The State Boys Rebellion. Simon and Schuster.

Fernald, W.E. (1912). The Burden of Feeblemindedness. Journal of Psycho-Asthenics. Retrieved from Massachusetts Medical Society: http://www.massmed.org/About/MMS-Leadership/History/The-Burden-ofFeeble-Mindedness/\#.WS2m-TOZNE4

Freeden, M. (2003). Ideology: A Very Short Introduction. Oxford, Oxford University Press.

Gadow, G. (2007). Statement by Gregory Gadow, Sponsor of I-957 (the Defense of Marriage Initiative), WA-DOMA. 2007.

Goddard, H. H. (1912). The Kallikak Family: A Study in the Heredity of Feeblemindedness. New York, Macmillan.

Gottfredson, L. S. (2005). "What if the Hereditarian Hypothesis is True?" Psychology, Public Policy, and Law 11(2): 311-319.

Grant, M. (1916). The passing of the great race; or, The racial basis of European history. New York,, Charles Scribner \& Sons.

Grumet, M. (1988). Bitter Milk: Women and Teaching. Amherst, University of Massachusetts Press.

Kevles, D. J. (1985). In the Name of Eugenics: Genetics and the Uses of Human Heredity. Berkeley, University of California Press.

Kozol, J. (2005). The Shame of the Nation: The Restoration of Apartheid Schooling in America. New York, Crown.

Kuhl, S. (1994). The Nazi Connection: Eugenics, American Racism, and German National Socialism. New York, Oxford University Press.

Lauren, P. G. (1988/1996). Power and Prejudice: The Politics and Diplomacy of Racial Discrimination, 2nd Edition. Boulder, Westview Press.

Ludmerer, K. M. (1972). Genetics and American Society: A Historical Appraisal. Baltimore, Johns Hopkins University Press.

Ordover, N. (2003). American eugenics: race, queer anatomy, and the science of nationalism. Minneapolis, University of Minnesota Press.

Paige, R. (2003). Remarks of Secretary Paige at the Brookings Institution's Accountability Conference. 2007.

Paul, D. B. (1998). The Politics of Heredity: Essays on Eugenics, Biomedicine, and the Nature-Nurture Debate. Albany, State University of New York Press.

Pinar, W. F. (2004). What is Curriculum Theory? Mahwah, NJ, Lawrence Erlbaum.

Roberts-Miller, P. (1999). Voices in the Wilderness: Public Discourse and the Paradox of Puritan Rhetoric. Tuscaloosa, University of Alabama Press.

Schafer, S. (2007). Clemson University probes racist party, The Boston Globe. 2007.

Shapiro, T. (2005). The Hidden Cost of Being African American: how wealth perpetuates inequality. New York, Oxford University Press.

Spellings, M. (2007b). Secretary Spellings' Remarks on the Fifth Anniversary of the No Child Left Behind Act, U.S. Dept. of Ed. 2007.

Steinberg, S. (1995). Turning Back: The Retreat from Racial Justice in American Thought and Policy. Boston, Beacon Press.

Stepan, N. L. (1991). The Hour of Eugenics: Race, Gender, and Nation in Latin America. Ithaca, Cornell University Press. 
Stoddard, L. (1920). The Rising Tide of Color: Against White World Supremacy. New York, Charles Scribner's Sons.

Tomlinson, S. (2005). Head Masters: Phrenology, Secular Education, and Nineteenth Century Social Thought. Tuscaloosa, The University of Alabama Press.

White, J. (2006). Intelligence, Destiny, and Education: The Ideological Roots of Intelligence Testing. Oxford, Routledge.

Wiggam, A. E. (1924). The Fruit of the Family Tree. Indianapolis, The Bobbs-Merrill Company Publishers.

Wiggam, A. E. (1927). The next age of man. Indianapolis,, The Bobbs-Merrill Company.

Winfield, A. G. (2007). Eugenics and Eduation in America: Institutionalized Racism and the Implications of History, Ideology, and Memory. New York, Peter Lang.

Winfield, A.G. and Canestrari, A.S, (2012). "Beware Reformers Bearing Gifts: How the Right Uses the Language of Social Justice to Reinforce Inequity.” In Becoming and Being a Teacher: Confronting Traditional Norms to Create New Democratic Realities, Thomas, P.L., editor, Mahwah, NJ: Peter :Lang Publishing.

Wise, T. (2005). Racism, Free Speech, and the College Campus, Znet. 2007.

Zahn, P. (2006). Zahn: Show on racism provokes strong reaction, CNN. 2007.

Zinn, H. (1980). A People's History of the United States. New York, Harper Perennial. 